\title{
Subversion, Perversion and the Aesthetics of Eroticism in The Bluest Eye, Beloved and Song of Soloman of Toni Morrison
}

\author{
J.P. Aggarwal \\ Lovely Professional University, Phagwara, Punjab
}

\begin{abstract}
The novels of Toni Morrison depict her tirade against the forces of white hegemony; she has raised a cry of Black women in America. The Bluest Eye, Beloved and Song of Soloman use the tools of subversion, perversion and eroticism to depict the traumatic experiences of the Black women protagonists. Toni Morrison's main concern is to tell the world how the Blacks are dehumanized. Her novels depict the cancerous virus of hatred and racial antagonism and gender discrimination. She uses grotesque, magic, the gruesome and elements of folk tale to depict the psychological depression and mental disorder of her women protagonists. The present research paper digs out the dilemmas and absurdities of the Blacks who are caught in the trap of perverse behavior and erotic sensibility.
\end{abstract}

Keywords: Dilemmas, Eroticism, Sexuality, Perversion, absurdities, Racial, Consciousness, Excavation

Morrison published The Bluest Eyes, (1970), Song of Solomon (1978) and Beloved (1991), to represent Black women's experience in a racist society. Morrison uses the techniques of grotesque, images of perversion and erotic to depict the inner turbulent world of Milkman Dead, Pilate, Sethe, Pauline Breedlove and Cholly Breedlove. Kathryn Hume published her seminal book Fantasy and Mimesis: Response to Reality in Western Literature (1984) in which she described the significance of the techniques of subversion and fantasy in visualizing the total reality. She opines that "successful fantasy persuades us to consider the situation as it were possible." (Fantasy and Mimesis 167) Morrison's use of grotesque is very effective in weaving the complex plots of her novels as she blurs realism. Morrison has depicted the physical and mental deformity of her protagonists to intensify the sufferings of the Blacks struggling in the White dominated community in America. Pauline Breedlove of The Bluest Eyes suffers deformity because of an unfortunate accident. All her dreams of beauty are shattered being a crippled girl of a twisted foot. She was just two years old when a rusty nail pierced her foot. Morrison ironically comments that "this saved Pauline Williams from total anonymity." (The Bluest Eyes 88) Indeed the plight of Pauline is of a great magnitude; she suffers psychological disorder in the novel. Pauline's twisted foot is given fantastic charm which captivated Cholly Breedlove when he first sees Pauline for the first time. The tool of subversion is very powerful in bringing Cholly and Pauline near. Morrison described in detail the ugly features of Pauline in the early part of the novel but in an erotic situation Cholly shows her perversion when he kisses her leg in sexual frenzy. Morrison focuses on the plight of Pauline depicting the cruelty of the unkind world. Pauline is limping wearing heels; her marriage brings her anguish, alienation and boredom. Her deformed foot brings 
awareness in her life stimulating her to face the existential reality. Freud "insisted that our civilization is a repressive one. There is a conflict between the demands of conformity and the demands of our instinctive energies, explicitly sexual". (Quoted in R.D. Laing, The Divided Self 13)

Morrison begins her novel with the images and metaphors of "seeds and black dirt" borrowed from the parable of seeds from the Bible. The novelist refers to "lust and despair" which are going to be powerful forces in the novel. Morrison comments thus: "He was full of lust and looked depressed always.. What is clear now is that all of that hope, fear, lust, love and grief, nothing remains but Pecola and the unyielding earth." (The Bluest Eye 5)

It is very essential to investigate the forces of poverty, marginalization and oppressive white dominated society that stifled his sensibility and turned him a beast. He was abandoned by his parents when he was born. Old Aunt Jimmy nurtured him. Cholly was a crazy about love and sex as Morrison describes his pervert nature thus: "when she made him sleep with her for warmth in winter and he could see her old wrinkled breasts sagging in her nightgown." (132) The critics have expressed their divergent opinions on the rape of Pecola. Bakerman observes that Cholly experienced "failure in love", he was a drifter ridiculed by the white men during his first sexual encounter with Darlene." (Bakerman 544)Toni Morrison expresses Cholly's disgust thus: " he "looked at Darlene. He hated her. He almost wished he could do it- -long, hard, and painfully, he hated her so much" (The Bluest Eyes 148). Two white men watch him when he is enjoying sexual experience for the first time. Mermann Jozwiak observes that Pecola's rape is the outcome of his "hatred for the past". She argued that "Cholly hated the female body" (Jozwiak 195).so his rape of his daughter was not a surprising event.

Morrison uses the techniques of subversion and perversion in the rape episode in her novel. He never regarded Aunt Jimmy as her real mother and felt disgusted sharing a bed with her in winter nights. He is victim of perversion and subversion in his loveless relationship with his Aunt who reared her. He continues his meaningless life in a white dominated world. Cholly is always haunted by his guilt consciousness as he never dares to look into the eyes of his Aunt Jimmy. Morrison depicts his perverted mind thus: He considers that "if he looked her in the face, he would see those haunted, loving eyes. The hauntedness would irritate him; the love would move him to fury" (The Bluest Eye 161) Freud "insisted that our civilization is a repressive one. There is a conflict between the demands of conformity and the demands of our instinctive energies, explicitly sexual" (Quoted in R.D. Laing, The Divided Self 13) Cholly is sick and decadent; he is the victim of mental disorder. Freud propounded his theory of hysteria on the basis of his investigation of Dora. He propounded the theory and contended that symptoms of hysteria stem from psychological trauma or sexual problems. In a fit of depression he sees his daughter eleven years old Pecola washing dishes in the kitchen alone. He is drunk; he sees his daughter's crippled foot. Now his existential despair turns into sexual passion as her foot becomes a fetish image. In The Feminist Reader, Morrison contends that fetishization is a strategy often used to assert the categorical absolutism of civilization and savagery." (The Feminist Reader 39) Morrison exposes the cruelty of family which plays dominant role in crushing the individuality Lucy Irigaray also observes the same sentiments in Ce Sexe thus: "The family has always been the privileged locus of the exploitation of women." Feminisms 429)

The plot of the novel excavates the inner tensions and anxieties of Cholly. Sartre expresses this anxiety of the individual thus in his famous book Being and Nothingness:

One may find oneself enlivened and the sense of one's own being enhanced by the other, or one may experience the other as deadening and impoverishing. A person may have come to 
anticipate that any possible relationship with another will have the latter consequences. Any other is then a threat to his 'self' (Quoted in R.D. Laing, The Divided Self 49)

Pecola does enjoy brief sexual exhilaration as a young bride but soon the euphoria ends as Cholly gets lost in watching the movies and Pecola keeping up the illusion of her beauty: "I' member one time I went to see Clark Gable and Jean Harlow. I fixed my hair up like I'd seen hers on a magazine." (The Bluest Eye 97). Pecola finds her front tooth fallen; the element of grotesque is introduced to set aside the serious episode of rape. Pecola's fallen tooth symbolizes her traumatic married life. Pecola expresses her ambivalent attitude of life and existence thus:

Here I was, five months pregnant, trying to look like Jean Harlow, and a front tooth gone. Everything went then. Look like I just didn't care no more after that. I let my hair go back, plaited it up, and settled down to just being ugly. (The Bluest Eye 98).

The plot of the novel is packed with the episodes of subversion, perversion and aberrations of Cholly. For him family ties are grotesque and life is meaningless in the colonized white dominated society. In his youth he was a rebel killing three white men. He landed in the prison developing savage and brutish behavior. Morrison portrays is his psychic disintegration thus:

Abandoned in a junk heap by his mother, rejected for a crap game by his father, there was nothing more to lose. He was alone with his own perceptions and appetites, and they alone interested him. (The Bluest Eye 126).

Soaphead Church is another repulsive protagonist expressing his deviant behavior. Being a mulatto, he grows into a misanthrope. In his case subversion technique is quite appealing since he loves chaos and disorder; loves unnatural objects just to express his perverse vision of life. Soaphead Church is nihilistic, melancholic and passionate lover of lewd sexuality. He curses God for creating a disorderly world where living is hellish wrought with existential despair.

All these abnormal tastes make him a bizarre character representing the imminent collapse of civilization. His unnatural liking for used objects and disorder and decay of this world; his melancholic disposition and his obscene sexuality make him a bizarre figure. He blames God for creating an imperfect world. Harihar Kukkarni observes that the novel The Bluest Eye is The Waste Land of Toni Morrison presenting bleak environment." (IJAS 23)

Morrison continues the themes of subversion and perversion in her novel Sula (1983) Sula is a powerful woman protagonist of Morrison portrayed on the tradition of Gothic fiction and fol tales of primitive societies. In Gothic novels Dark Lady is a popular figure and Sula emerges as a devilish witch who dares to subvert the patriarchal traditions in her quest for identity. Her birthmark is a source of mystery and terror to many people who encounter her. She looks like a poisonous snake. Her snake like birthmark characterizes her as an image of subversion. Her sexual bouts represent her erotic perversion. Morrison comments thus: "Sula defies the assumption of a self that is knowable, centered and unified and posits instead a view of the self as multiple, fluid and relational."(Sula 47). Some critics observe that her demonic figure symbolizes the confrontation of the Blacks with demonic forces. Sula is a symbol of subversive forces as she has passion to transgress all patriarchal traditions. All that lives in Bottoms call her "transgressive figure". She is afflicted by the rudeness of her grandmother; her mother neglects her so being lonely she turned into a savage. Morrison depicts her subversion of feminine nature thus: "She picks up a man, drops a man, the same way a man picks up a woman drops a woman." (Sula 27) Sula refuses to be passive slave woman an in her encounter with Irish boys she emerges as an image of horror and terror reminding us the tales of horror of Edgar Allan Poe. She slashes her tip 
off her finger with a knife and terrifies them with her monstrous call: "If I can do that to myself, what you suppose I'll do to you?" (Sula 54-55).

Morrison published her famous novel Song of Solomon in 1978 experimenting in the technique of subversion and perversion in fiction. Pilate Dead disrupts the biological order of the universe born without a navel; he thinks that he is an outsider in this world just wandering as a picker. His strange figure is source of great excitement to his people; all women felt a pity for him: "And they also felt pity along with their terror of having been in the company of something God never made."(Song of Solomon 144) E. Raja Rao observes that Pilate's lack of a navel amounted to a positive disturbance in the female biological world." (IJAS 55) Morrison uses the technique of subversion in creating the character of Pilate in Song of Solomon. She is an exceptional Black child; her mother lost her life after giving her birth. Abject poverty poor medical aid were the predominant causes of her unfortunate death. Such tragedies are very common with the Black mothers. When Milkman is in the dilemmas of life struggling in his process of identify formation it is Pilate who supports Milkman to resolve the riddle of his life. Pilate too had been very unfortunate because his mother died after giving birth to him. Macon looked after Pilate and gave her the love of a mother. "At one time she had been the dearest thing in the world to him" (Song of Solomon 20). Morrison has given supernatural traits to Pilate; she has no attachment for materialistic things of life as she discards money, fashion and other worldly things for which women are crazy. Jesus lives in her soul as her company is always soothing. Pilate lives in the world of reality; she knows that she is Black and she is proud of her Black consciousness. Pilate is proud of her Black ancestors and firmly believes that "Black is Beautiful". Ruth suffers alienation because of her lack of adjustment with Macon in her early married life. Ruth's traumatic isolation can be observed from the following lines of the text: "I lived in a great big house that pressed me into a small package" ((Song of Solomon 124). She has given expression to her unique supernatural figure thus: "I am not a strange woman but a small one" ((Song of Solomon 124). Pilot saves the life of Milkman and uses her all sources to save Milkman and Guitar when they are arrested by police on the false allegations of theft. She pawned all her jewelry to help Hagar to survive.

Pilot lives in her own world; she is guided by her own principles. She subverts the Black value system by her uncanny habits. Her lips move all the time threatening the people as Morrison comments:

. She was a strange child. When she was a baby she would keep things in her mouth to the horrors of others. She would eat straw from brooms, gristle, buttons, seeds, leaves, string, and her favorite, ... rubber bands and India rubber erasers. (Song of Solomon 30 Italics are mine ).

Pilate holds bizarre ideas about death. Hagar explains to Milkman that "Mama can go for months without food. Like a lizard." (Song of Solomon 48)

Milkman Dead of the novel is another unique character symbolizing subversion and perversion. His very name is the "product of prolonged breast deeding of his mother".( Song of Solomon 6o). Milkman is psychologically oppressed by his mysterious name that brought him eternal shame. J. Brooks Bouson opines that the protagonist is a supernatural being; Morrison has used the technique of magic realism in his creation. His unique name suggests that he is cut off from his old heritage. In the Black world of people there is no such man ever born with this exceptional name. Like Angela Carter, Morrison used old allusions, cultural images drawn from antique African history in the plot of Song of Solomon. Like Joe Christmas of William Faulkner of The Light in August Milkman is psychologically obsessed with the nature of his black identity. 
Ironically he gives vent to his wounded heart by confessing that he carried with him all the "shit" of his family. Morrison has repeatedly referred to his guilt-consciousness' articulating "his racial shame.". (Song of Solomon 75). The problem with Milkman Dead is that he is haunted by his dismal past and feels obsessed with void. He is leading a purposeless life being caught in the web of false illusions. He is energetic, anxious groping in the dark to find a meaning of life in the white dominated society. Moral and spiritual dilemmas and uncertainties of life put heavy burden on his psyche..

Morrison begins her novel Song of Solomon like a ritual of sacrifice. The opening chapter presents the horrifying scene of a flying man who commits suicide. Morrison uses the ancient myth of flying drawn from ancient African history and the "flying motif" has vital significance in the life of Milkman Dead. It is believed that in antiquity the Africans had the magical power to fly. The ritual of flying has been used by Morrison figuratively. In the first chapter of the novel Morrison give the metaphor of flying as the protagonist begins his quest. Marilyn Sander Mobley published her famous article Myth as Usable Past in which she investigated and examined the nature of the journey of Milkman and the "trials and tribulations he faces during his journey". (Mobley 97). Morrison depicts the conflicts of Milkman who is crazy to fly in the white dominated world to find out the real meaning of his life and to dig out his original Black heritage. Milkman transgresses all the norms of his Black community beginning his journey with a passion to find out gold. He falsely believes that if he were rich and wealthy he would create his niche in the white world. The novelist has extensively used the images of Gothic tradition and bewitching imagery and romance to translate the inner conflicts of the protagonist.. The plot of the novel may be regarded as an epical journey of Milkman Dead to explore the nature of his true identity and to dig out the old roots of his heritage. Macon teaches him the values of materialism to Milkman thus: "Let me tell you right now the one important thing you'll ever need to know: Own things. And let the things you own other things. Then you will own yourself and other people too" ( Song of Solomon 55). Macon tries his best to dissuade Milkman to imitate the values of Pilate:

Pilate can't teach you a thing in this world. You must learn to own things and see what is good and what is bad for you. May be the next, but not this one: Own things. And let the things you own, own other things. Then you'll own yourself and other people too (Song of Solomon 55).

Eleanor Branch published the article “Through the Maze of the Oedipal: Milkman's Search of Self in Song of Solomon" tin which she discussed Morrison's indebtedness to "an appropriation and critique of both African and Western mythologies.... Morrison's task in the novel is reparation of the old mythological aesthetic and the production of a new one." (Eleanor Branch 55) Morrison used elements of subversion; perversion and eroticism to conceive the character of Milkman Dead. Ruth was leading a lonely life without her husband when she started milking Milkman Dead. She gave over breast-feeding to Milkman obviously her action was the result of her sexual repression. Homeric witch goddess Circe is introduced to inaugurate Milkman's journey. Valerie Smith wrote in Self-Discovery and Authority in Afro-American Narrative (1987) that Morrison subversion technique is very effective in creating an uncommon Blackman and his uncommon journey of life. The birth of Milkman was the result of supernatural forces. His mother wanted to terminate the pregnancy but Milkman was born as an "inescapable event". (Valerie Smith 152). Interestingly Milkman took birth at a time when Robert Smith fell from top level of the Mercy hospital. Aunt Pilate had predicted the supernatural birth of Milkman Dead saying that soon "a new bird will fall on the earth". (Song of Solomon 9) M. Royster is another critic who observes that 
his birth "is depicted by a series of episodes during which he discovers his relationship to his family" (Royster 419). Mobley avers in Politics of Representation that "Song of Solomon invites us to remember the expensive price of freedom and the struggle the descendents of enslaved Africans had to wage to obtain what racial identity once denied" (Mobley212).

Pilate emerges as a "natural healer," in the novel. Pilate symbolizes love and tenderness; has an "alien's compassion for troubled people," has "respect for other people's privacy," (Song of Solomon 336) Pilate is blessed with uncommon force of moral strength and spiritual power to bring magical transformation in Milkman Dead. She uses the tonic of love, tenderness and care to transform Milkman Dead giving him the right direction of life. Toni Morrison documents transformed and rejuvenated Milkman thus: "Now he was behaving with this strange woman as though having the name was a matter of deep personal pride, as though she has tried to expel him from a very special group, in which he not only belonged, but had exclusive rights" (Song of Solomon 39). Pilate acts as a godmother to him handling him like an expert psychologist. Her natural therapy works as Milkman shows changes in his aggressive and sullen behavior. Pilate nurtures him with the elixir of love and compassion. She sings of the old story of the glory of his father. She tells him about his old grandmother who was a great woman. She exhorts him narrating the old tales of her childhood in a soothing and pleasant tone. Pilate inspires Milkman thus:: "You all must be the dumbest unhung Negros on earth. What they telling you in them schools? You say 'Hi' to pigs and sheep when you want them to move. When you tell a human being 'Hi,' he ought to get up and knock you down” (Song of Solomon 37). Pilate teaches Milkman is the values of his parentage thus:

She who cooked him his first perfect egg, who had shown him the sky, the blue of it, which was like her mother's ribbons, so that from then on when he looked at it, it had no distance, no remoteness, but was intimate, familiar, like a room that he loved in, a place where he belonged" (Song of Solomon 209).

To conclude, Toni Morrison employs the tools of subversion, perversion and eroticism to depict the traumatic experiences of Black women who are treated as fodder by the whites in Afro-

American society. These techniques are at once new and innovative establishing Morrison as the great American writer of her age.

\section{Works Cited}

Bakerman, Jane S. 1981. "Failures of Love: Female Initiation in the Novels of Toni Morrison." American Literature. 52.4 541-564. Print.

Bouson, J. Brooks. 200o. Quiet as It's Kept: Shame, Trauma, and Race in the Novels of Toni Morrison. Albany, NY: State U of New York P

Conner, Marc C. 200o. "From the Sublime to the Beautiful: The Aesthetic Progression of Toni

Morrison.” The Aesthetics of Toni Morrison: Speaking the Unspeakable. Ed, Marc C. Conner. Jackson: UP of Mississippi.

Mermann-Jozwiak, Elizabeth.20o1. "Re-membering the Body: Body Politics in Toni Morrison's The Bluest Eye." LIT: Literature Interpretation Theory.

Morrison, Toni. 2009. Interviewed by Bonnie Angelo. "The Pain of Being Black." Time. Time, 22 May 1989. .1994. The Bluest Eye. New York: Penguin Books.

Coontz, Stephanie. 1992. The Way We Never Were: American Families and the Nostalgia Trap. New York: Harper-Collins. 
103 Subversion, Perversion and the Aesthetics of Eroticism in The Bluest Eye, Beloved and Song of Soloman of Toni Morrison

Cooper, Barbara E. 1989. "Milkman's Search for Family in Toni Morrison's Song of Solomon." CLA Journal XXXIII.2 (Dec. 1989): 145-56.

Lee, Dorothy H. 1982. "Song of Solomon: To Ride the Air." Black American Literary Forum 16.2 (Summer 1982): 64-70.

Mobley, Marilyn Sander. 1991. "Myth as Usable Past: Affirmation of Community and Self in Song of Solomon." Folk Roots and Mythic Wings in Sarah Orne Jewett and Toni Morrison. Barton Rouge \& London: Louisiana State UP. 91-133. Print.

---. 1995. "The Politics of Representation: Black Middle Class Identity in the Novels of Toni Morrison.” Research in Race and Ethnic Relations 8: 201-21.

Morrison, Toni. 1987. Song of Solomon.New York: Penguin Publishers.

Peach, Linden. 1995. Modern Novelists: Toni Morrison. London: Macmillan.

Plakkoottam, Alphy. J. 1993. "The Dynamics of Man-Woman Relationships in Toni Morrison's Song of Solomon and Mariama Ba's So Long a Letter." Indian Journal of American Studies 23.2 (Summer 1993): 8590.

Royster, Philip M. 1982. "Milkman's Flying: The Scapegoat Transcended in Toni Morrison's Song of Solomon." CLA Journal 24 (June 1982): 419-40.

Samuels, Wilfred D. 1981. "Liminality and the Search for Self in Toni Morrison's Song of Solomon." Minority Voices 5 (1981): 59-68.

Dr. J.P. Aggarwal is Associate Professor, Department of English, Lovely Professional University, Phagwara, Punjab. 